\title{
Criminologie
}

\section{La criminalisation du trafic de migrants au Canada}

\section{Estibaliz Jimenez}

Volume 46, numéro 1, printemps 2013

La criminalisation de l'immigration

URI : https://id.erudit.org/iderudit/1015296ar

DOI : https://doi.org/10.7202/1015296ar

Aller au sommaire du numéro

Éditeur(s)

Les Presses de l’Université de Montréal

ISSN

0316-0041 (imprimé)

1492-1367 (numérique)

Découvrir la revue

Citer cet article

Jimenez, E. (2013). La criminalisation du trafic de migrants au Canada.

Criminologie, 46(1), 131-156. https://doi.org/10.7202/1015296ar

\section{Résumé de l'article}

La migration irrégulière est perçue par la communauté internationale comme un enjeu sécuritaire. La criminalisation de l'immigration devient alors un outil de contrôle migratoire et de sécurisation des frontières. Au cours des dernières années, le Canada a adopté une approche punitive et un recours plus important à la criminalisation de l'immigration irrégulière, avec des peines pouvant atteindre l'emprisonnement à vie. Paradoxalement, malgré un renforcement normatif, dont l'adoption de peines minimales obligatoires et l'augmentation des peines maximales, les tribunaux canadiens imposent aux passeurs des peines d'emprisonnement de courte durée et généralement des peines d'emprisonnement avec sursis à purger dans la collectivité. Le présent article présente les résultats des analyses législatives et jurisprudentielles relatives au trafic de migrants au Canada. Les résultats démontrent que les peines octroyées par les tribunaux ne sont pas proportionnelles aux discours politiques et médiatiques alarmistes à l'égard de la menace que représente l’organisation de l'entrée illégale.
Ce document est protégé par la loi sur le droit d'auteur. L'utilisation des services d'Érudit (y compris la reproduction) est assujettie à sa politique d'utilisation que vous pouvez consulter en ligne.

https://apropos.erudit.org/fr/usagers/politique-dutilisation/ 


\title{
La criminalisation du trafic de migrants au Canada
}

\author{
Estibaliz Jimenez \\ Chercheure invitée, École de criminologie, Université de Montréal \\ Professeure associée \\ Faculté de droit, Université de Sherbrooke \\ Étudiante postdoctorale \\ Chaire de recherche du Canada sur l'évaluation des actions publiques \\ à l'égard des jeunes et des populations vulnérables (CRÉVAJ) \\ École nationale d'administration publique (ENAP) \\ estibaliz.jimenez@umontreal.ca
}

\begin{abstract}
RÉSUMÉ • La migration irrégulière est perçue par la communauté internationale comme un enjeu sécuritaire. La criminalisation de l'immigration devient alors un outil de contrôle migratoire et de sécurisation des frontières. Au cours des dernières années, le Canada a adopté une approche punitive et un recours plus important à la criminalisation de l'immigration irrégulière, avec des peines pouvant atteindre l'emprisonnement à vie. Paradoxalement, malgré un renforcement normatif, dont l'adoption de peines minimales obligatoires et l'augmentation des peines maximales, les tribunaux canadiens imposent aux passeurs des peines d'emprisonnement de courte durée et généralement des peines d'emprisonnement avec sursis à purger dans la collectivité. Le présent article présente les résultats des analyses législatives et jurisprudentielles relatives au trafic de migrants au Canada. Les résultats démontrent que les peines octroyées par les tribunaux ne sont pas proportionnelles aux discours politiques et médiatiques alarmistes à l'égard de la menace que représente l'organisation de l'entrée illégale.
\end{abstract}

MOTS-CLÉS - Trafic de migrants, sécurisation des frontières, criminalisation, analyse jurisprudentielle.

\section{Introduction}

Ces dernières années, la question de l'immigration irrégulière a suscité de nombreux débats au sein des Nations Unies, de l'Union européenne et des pays nord-américains sur le crime organisé transnational, le trafic 
de migrants et la traite des personnes. Les États poursuivent l'élaboration de lois, de conventions et d'accords bilatéraux et régionaux pour faire face à ces phénomènes migratoires (Jimenez, 2009a, 2009b, 2010a).

Au cours des dernières années, le Parlement du Canada a entrepris un renforcement législatif dans le domaine de l'immigration et du droit criminel. Avec l'adoption en 2001 de la Loi sur l'immigration et la protection des réfugiés (LIPR), il existe une augmentation de la répression de l'organisation de l'entrée illégale. Toutefois, malgré le renforcement normatif et l'augmentation des peines maximales, l'analyse jurisprudentielle démontre que les tribunaux canadiens imposent des peines d'emprisonnement de courte durée et généralement des peines d'emprisonnement avec sursis à purger dans la collectivité.

Le présent article est divisé en deux parties. Dans la première partie, l'analyse législative relative au trafic de migrants est présentée; d'abord la législation internationale et ensuite nationale. Dans la seconde partie, les résultats d'analyse jurisprudentielle de telles législations sont présentés.

\section{La problématisation de l'immigration}

Nous vivons dans un contexte où la sécurisation des frontières est devenue une des priorités des États (Bigo, 2005, 2007). Ce concept explique le processus de problématisation de l'immigration par les États occidentaux qui, après avoir identifié la menace existentielle que représente l'immigration, légitiment le recours à des mesures exceptionnelles pour contrer le problème. Dans la foulée des attentats du 11 septembre 2001 et, sous la menace du terrorisme, les États occidentaux ont adopté des lois antiterroristes et d'immigration privilégiant le paradigme de la sécurité nationale au détriment de la protection des droits fondamentaux, notamment ceux des migrants. Au nom de la sécurité nationale, ils resserrent le contrôle migratoire et intensifient les mesures de maintien de l'ordre aux frontières (Crépeau et Jimenez, 2002; Lowry, 2002; Bigo, 2005, 2007; Crépeau et Nakache, 2006; Crépeau et al., 2007, 2009; Jimenez, 2010a, 2010b). La tendance est de fermer les frontières nationales pour se sentir plus en sécurité sur le territoire souverain, convaincu d'ainsi se protéger d'une menace terroriste problématisée comme venant d'ailleurs. L'association générale, très médiatisée, qui en découle, entre migrants, réfugiés et terroristes, en sort renforcée (Crépeau et Jimenez, 2002; Jimenez, 2010a, 2010b). Nous faisons face à une ins- 
trumentalisation des événements tragiques du 11 septembre 2001 par les États (Jimenez, 2010a, 2010b) à laquelle le Canada participe en pratiquant une politique sécuritaire et défensive envers les migrants (Macklin, 2001 ; Crépeau et Jimenez, 2002; Crépeau et Nakache, 2006; Crépeau et al., 2007, 2009; Jimenez, 2010a, 2010b).

\section{La criminalisation internationale et nationale du trafic de migrants}

Cet article présente d'abord les résultats d'analyse législative et ensuite jurisprudentielle des dispositions canadiennes criminalisant l'immigration irrégulière. L'analyse législative va comprendre l'étude de la législation internationale et canadienne relative au trafic de migrants.

\section{La criminalisation internationale du trafic de migrants}

Bien que la participation des groupes criminels organisés dans le trafic de migrants soit débattue par une partie de la doctrine (Finckenauer et Waring, 1998; Skeldon, 2000; Chin, 2000, 2001 ; Koslowski, 2001; Kyle et Liang, 2001), l'idée que le trafic de migrants et les groupes criminels soient étroitement liés serait plutôt répandue chez les politiciens, les organisations d'application de la loi et les législateurs. Ce lien établi entre le trafic de migrants et le crime organisé légitime et justifie entre autres la lutte contre l'immigration irrégulière (Jimenez, 2010a). C'est pour cette raison que la communauté internationale a adopté le Protocole contre le trafic illicite de migrants par terre, mer et air, additionnel à la Convention des Nations Unies contre la criminalité transnationale organisée 1.

Dans le but d'accélérer les procédures de poursuite et d'éviter d'offrir le refuge aux passeurs, les États parties au Protocole contre le trafic sont tenus de punir le trafic de migrants et de conférer le caractère d'infraction pénale au «trafic illicite de migrants ${ }^{2} »$. Le Protocole exige l'incrimination, à la fois, d'assurer l'entrée illégale, «trafic illicite» (art. 3 [a]

1. Protocole contre le trafic illicite de migrants par terre, air et mer additionnel à la Convention des Nations Unies contre la criminalité transnationale organisée, adopté le 15 novembre 2000 et entré en vigueur le 28 janvier 2004. Consulté le 4 février 2013, http://www.uncjin.org/ Documents/Conventions/dcatoc/final_documents_2/convention_smug_french.pdf [Ciaprès dénommé Protocole contre le trafic].

2. Voir Protocole contre le trafic de migrants, art. 6.

1. Chaque État partie adopte les mesures législatives et autres nécessaires pour conférer le caractère d'infraction pénale, lorsque les actes ont été commis inten- 
et art. $6.1[\mathrm{a}])$, et de faciliter la résidence par des moyens illégaux (art. $6.1[c])$. Le Protocole oblige également les États parties à incriminer le fait de «fabriquer et de procurer, de fournir ou de posséder un document de voyage ou d'identité frauduleux» (art. 6.1 (b)).

Les pays signataires du Protocole contre le trafic sont tenus de renforcer leur législation nationale et de criminaliser l'introduction clandestine de migrants, ainsi que de coopérer internationalement en matière de répression. Un des objectifs du Protocole est de criminaliser les actes de trafic et de s'assurer que les peines contre les trafiquants sont assez sévères pour avoir un effet dissuasif.

\section{La criminalisation canadienne du trafic de migrants}

Entre le $1^{\text {er }}$ avril 2010 et le 31 mars 2011, les autorités canadiennes estmaient qu'environ 44000 migrants irréguliers étaient recherchés au pays pour être déportés, dont 4615 auraient demandé l'asile au Québec (Meunier, 2012). En 2010, selon l'ASFC, 23167 migrants irréguliers auraient franchi les frontières canadiennes (Meunier, 2012). De ce nombre, 810 l'ont fait par bateau, c'est 623 personnes de plus qu'en 2009. L'arrivée, en 2010, du Sun Sea à Vancouver avec à son bord près de 500 demandeurs d'asile a toutefois fait augmenter ces statistiques (Meunier, 2012). Par contre, le nombre de voyageurs irréguliers interceptés avec de faux papiers à leur descente d'avion au Canada est en constante diminution depuis trois ans. Entre le $1^{\text {er }}$ janvier 2005 et le $1^{\text {er }}$ juillet 2011, les douaniers canadiens ont intercepté 14883 immigrants illégaux munis de documents de voyage contrefaits (De Pierrebourg, 2011).

Le Canada a signé le 14 décembre 2000 et ratifié le 13 mai 2002 le Protocole contre le trafic et le Protocole contre la traite des personnes (Canada, 2002). À cet effet, le Canada incrimine l'immigration irrégulière et le trafic des migrants par le Code criminel et la Loi sur l'immigration et la protection des réfugiés (LIPR).

tionnellement et pour en tirer, directement ou indirectement, un avantage financier ou autre avantage matériel:

a) Au trafic illicite de migrants;

b) Lorsque les actes ont été commis afin de permettre le trafic illicite de migrants:

i) À la fabrication d'un document de voyage ou d'identité frauduleux;

ii) Au fait de procurer, de fournir ou de posséder un tel document;

c) Au fait de permettre à une personne, qui n'est ni un ressortissant ni un résident permanent, de demeurer dans l'État concerné, sans satisfaire aux conditions nécessaires au séjour légal dans ledit État, par les moyens mentionnés à l’alinéa b) du présent paragraphe ou par tous autres moyens illégaux. 
Le Code criminel canadien dispose de plusieurs infractions connexes à l'immigration irrégulière, au trafic de migrants et à la traite des personnes. Il confère le caractère d'infraction pénale à la fabrication ou à l'usage d'un passeport, d'un certificat de citoyenneté, d'un certificat de naturalisation ou d'un faux document pour fin frauduleuse (art. 57 [1], [2], [3], 58 [1], 366, 367, 368). Par ailleurs, le Code criminel aggrave les peines lorsque l'infraction est commise au profit ou sous la direction d'une organisation criminelle (art. 718.2).

La Loi sur l'immigration et la protection des réfugiés, un instrument de choix pour criminaliser le trafic de migrants

Dans la logique d'une approche sécuritaire et de fermeture des frontières, le gouvernement du Canada a choisi de lutter et de punir l'immigration irrégulière et le trafic de migrants, notamment à travers la LIPR.

Lancienne Loi sur l'immigration comportait des peines sévères pour les personnes reconnues coupables d'introduction clandestine de migrants et d'activités connexes, pouvant aller jusqu'à une peine d'emprisonnement de dix ans en vertu des dispositions 94.1 et 94.2. En 2001, seulement trois semaines après les attentats du 11 septembre, une profonde réforme de la loi fédérale sur l'immigration a été adoptée, la LIPR. Le nouveau texte vise à renforcer les mesures d'incrimination destinées à empêcher l'arrivée au Canada des personnes non munies des documents requis. Diverses infractions y sont prévues, dont certaines existaient déjà sous le régime antérieur, mais qui font maintenant l'objet de peines plus sévères, dont organiser une entrée clandestine (art. 117), débarquer des gens en mer (art. 119), conseiller de faire une fausse déclaration (art. 126), faire une déclaration mensongère en vue d'encourager l'immigration au Canada (art. 127).

La LIPR alourdit les peines relatives au passage de clandestins et elle permet d'imposer des peines et des amendes pouvant atteindre un million de dollars et l'emprisonnement à vie. Elle prévoit la confiscation des biens des passeurs de clandestins et des trafiquants. Elle prévoit également deux facteurs aggravants dont le tribunal doit tenir compte dans le processus de détermination de la peine (art. 121):

- l'infraction a été commise au profit, pour le compte, ou sous la direction d'une organisation criminelle ou d'un groupe terroriste ou en association avec eux; 
- dans la perpétration de l'infraction, le délinquant a mis en danger la vie ou la sécurité des clandestins ou a causé des blessures ou le décès d'un ou de plusieurs clandestins.

Le 29 juin 2012, le gouvernement a adopté la Loi visant à protéger le système d'immigration du Canada, le controversé projet de loi C-31, et dont l'entrée en vigueur prochaine permettra, entre autres (Canada, 2012): de déclarer irrégulière l'arrivée de groupes de personnes au Canada et de faciliter les poursuites contre les passeurs de clandestins; d'accuser les propriétaires et les exploitants de navires pour l'utilisation de leur navire au profit du passage de clandestins; et de prévoir la détention obligatoire des migrants et des demandeurs d'asile objets de l'arrivée irrégulière. De plus, les modifications prévoient un régime progressif de peines d'emprisonnement minimales obligatoires conformément au nombre de personnes introduites illégalement au pays et l'existence de facteurs aggravants.

Avec l'augmentation des peines, le gouvernement envoie un signal clair à quiconque serait tenté de se livrer à des activités visant à faire entrer de façon illicite des migrants au Canada. On attire l'attention du choix, délibéré et calculé, du Canada de créer une infraction relative au trafic de migrants en vertu de la LIPR et non du Code criminel. En vertu du Code criminel, aucune personne ne peut être déclarée coupable d'un acte criminel à moins que le tribunal ne soit convaincu, hors de tout doute raisonnable, que l'accusé est coupable de l'infraction imputée. Or, dans le cadre de la LIPR, les tribunaux administratifs, comme la Commission de l'immigration et du statut de réfugié (CISR), ne sont pas liés pas ce fardeau. Il s'avère donc plus facile de déclarer une personne coupable de trafic par la LIPR.

Le Canada, comme État partie du Protocole contre le trafic, respecte ses engagements. Cependant, si le Canada s'est inspiré des instruments internationaux de lutte contre le trafic de migrants et le crime organisé, il va plus loin en matière de répression que les exigences adoptées par le Protocole.

La législation canadienne est plus sévère que le Protocole contre le trafic

Plusieurs différences importantes sont relevées entre la législation internationale et nationale. Premièrement, le Protocole contre le trafic est appli- 
cable uniquement lorsqu' "un groupe criminel organisé y est impliqué » (art. 4) à la différence de la LIPR où «quiconque sciemment organise» (art. 117). Donc, le Canada compte punir très sévèrement les personnes qui opèrent en dehors du cadre d'une organisation criminelle.

Deuxièmement, le critère «un avantage financier ou un autre avantage matériel» dans la définition du trafic (art. 3) a délibérément été introduit par les États parties au Protocole afin de souligner l'intention de punir uniquement les activités lucratives des groupes criminels organisés. Mais au Canada, si «l'infraction a été commise en vue de tirer un profit, que celui-ci ait été ou non réalisé » (art. 121[1] [c]), la Cour doit le considérer comme une circonstance aggravante et non comme un élément essentiel et constitutif au trafic. Le Canada prévoit également punir très sévèrement des individus qui ne sont pas motivés par un but lucratif, mais qui le sont par des préoccupations humanitaires. Finalement, en vertu de l'article 5 du Protocole, il existe une immunité pénale pour les migrants et les personnes qui les aident bénévolement. Le Protocole ne criminalise pas les migrants objets du trafic. Par contre, dans la LIPR, il n'y a que les migrants reconnus comme réfugiés qui sont exemptés de poursuites (art. 133).

Le Canada, à l'encontre du Protocole contre le trafic, punit des personnes qui ne sont pas membres des organisations criminelles. Des membres des familles ou des groupes de soutien telles les organisations religieuses ou non gouvernementales apportant une aide aux migrants pour des motifs humanitaires ou en raison de liens familiaux étroits courent également le risque d'être punis très sévèrement. Finalement, il faut souligner qu'au Canada, contrairement au Protocole, le migrant objet du trafic manque d'immunité pénale et en conséquence, il pourrait être sévèrement puni.

À ce titre, le 11 janvier 2013, la Cour suprême de la ColombieBritannique $^{3}$ a statué que l'article 117 de la LIPR viole la Charte canadienne des droits et libertés au motif qu'il criminalise les actions humanitaires visant à protéger les réfugiés.

\section{Méthodologie}

L'intérêt de cet article porte sur la manière dont les différentes dispositions prévues par la législation internationale et canadienne relative à 
l'immigration irrégulière et le trafic de migrants sont appliquées par les tribunaux canadiens.

L'analyse jurisprudentielle comprend l'examen de la jurisprudence des décisions des tribunaux pénaux canadiens (voir annexe). Les différentes décisions judiciaires analysées ont été repérées à l'aide de la banque de données comprenant la jurisprudence canadienne: Quicklaw. L'usage des différents mots-clés, comme "passeur», «clandestin» et «entrée illégale» ont servi à repérer les décisions pertinentes. Dix-neuf décisions ${ }^{4}$ jugées par différentes cours de justice et cours d'appel des différentes provinces canadiennes concernant le trafic de migrants au Canada ont été étudiées. Cette démarche méthodologique permet d'atteindre deux objectifs de recherche. Premièrement, comprendre la perception des tribunaux de la menace et des impacts négatifs que représentent le trafic de migrants et l'immigration irrégulière pour le Canada. Deuxièmement, connaitre l'application de la loi et le traitement judiciaire réservé à une infraction du trafic de migrants et les infractions connexes.

\section{Résultats de recherche}

Les peines ne sont pas proportionnelles aux discours alarmistes

Les discours des tribunaux pénaux à travers le Canada font l'unanimité: le trafic de migrants est une activité criminelle de nature très grave qui génère d'importants impacts négatifs et, en conséquence, il doit être sévèrement puni.

4. R. c. King Fong Yue, [1991] Ontario Provincial Court; Mabmood c. Canada, [2000] A.C.F. $\mathrm{n}^{\circ} 608$ (C.F. $1^{\text {ère }}$ inst. Ont.); R. c. Chowdhury, [2000] R.D.S.D. $\mathrm{n}^{\circ}$ 171, R.J.P.Q. 2000-171, J.Q. n 1004 (C.Q. Qué.); Chowdhury c. R.., [2002] J.Q. n 1597 (C.A.Q. Qué.); Chowdhury c. R., [2002] R.D.S.D. no 92, JCPQ 2002-9 (C.A.); R. c. Damani, [2003] O.J. $\mathrm{n}^{\circ}$ 5493, [2004] C.C.S. no 7615 (Ontario Court of Justice); R. c. Kadri [2004] O.J. no 5018; R. c. Mendez, [2004] O.J. n 5733 (Ontario Superior Court of Justice); R. c. Tongo, [2002] B.C.J. $n^{\circ} 2458$ (BC Prov. Ct. J.); R. c. Graca, [2003] O.J. no 2560 (Ontario Court of Justice); R. c. Graca, [2003] R.C.S. $\mathrm{n}^{\circ} 8676$, O.J. no $2560 ;$ R. c. $L i$, [2001] B.C.J. $\mathrm{n}^{\circ} 748$ (British Columbia Supreme Court); R. c. Li, Chen and Liu, [2002] 162 C.C.C. (3d) 360 (Ontario Court of Appeal); R. c. Li, [2002] O.J. $\mathrm{n}^{\circ} 438$ (Ontario Court of Appeal); R. c. Xu, [2001] O.J. ${ }^{\circ} 5864$ (Ontario Superior Court of Justice); R. c. Chen, [2001] B.C.J. ${ }^{\circ} 2983$ (British Columbia Supreme Court); R. c. Mubme, [1992] N.S.J. no 125. (Nova Scotia Provincial Court); United States v. Ramirez-Lopez, [2003] CA9-QL 12 (United State of Appeals for the Ninth Circuit United States v. Ramirez-Lopez, [2003] CA9-QL 12 (United State of Appeals for the Ninth Circui), R. c. Roo, unreported, (Ontario Court of Justice); R. c. Balchand, [2002], unreported, (Ontario Court of Justice); R. c. Graprasad and Samaroo, [2003] unreported, (Ontario Court of Justice). 
Les tribunaux pénaux adoptent un discours alarmiste à l'égard du trafic de migrants

Le parlement canadien a exprimé son souci à l'égard de la gravité de la nature du trafic de migrants au Canada. Cette préoccupation du législateur a été bien saisie par les tribunaux (R.c.Damani ${ }^{5}, R$. c. Mubme, $R$. c. Xu, R. c. Li, R. c. Mendez, R. c. Kadri).

The I.R.P.A ${ }^{6}$ was a strong response by Parliament to a growing problem of illegal migration of persons into this country. Part 3 recognizes the role of organized crime and persons who would profit from such activity and establishes severe penalties which are considered to be aggravated by profit, by involvement of organized crime and by the inhuman treatment of the migrants, including humiliation, degradation, death or bodily harm. (R. c. Tongo ${ }^{7}$ )

This is clearly a serious crime. Parliament has re-emphasized this point with new legislation and accompanying increased maximum penalties. The legislation referred to in Court is directed at immigration and security. In addition, as with basically all areas of criminal law, the fact that this is a conspiracy, in other words, a group of people organized to commit this offence, is of great concern. $\left(R . c . K a d r i^{8}\right)$

Les tribunaux soulèvent plusieurs impacts négatifs relatifs au trafic de migrants. Tout d'abord, le trafic de migrants est devenu une activité très lucrative. La rentabilité élevée du crime, qui se traduit en faible risque et haut profit pour les trafiquants, est perçue comme la cause de la prolifération du phénomène du trafic de migrants. Il semblerait que les bénéfices provenant du trafic de migrants sont encore plus élevés que ceux du marché de la drogue.

Smuggling of human beings has been described as the crime of the '90's. It has become so profitable that individuals involved in the drug trade are now switching to this type of smuggling. The profits are as high and to date, penalties imposed have not been severe. [...] It is the Crown's contention that a clear and unmistakable judicial message must be sent out to those who would engage in trafficking of humans for profit. (R. c. Mubme, Michel Paré, procureur, pour la poursuite)

5. R. c. Damani, [2003] O.J. $n^{\circ}$ 5493, [2004] C.C.S. $\mathrm{n}^{\circ} 7615$ (Ontario Court of Justice).

6. L'acronyme IRPA est la traduction de la LIPR en anglais.

7. R. c. Tongo, [2002] B.C.J. $\mathrm{n}^{\circ} 2458$ (BC Prov. Ct. J.).

8. R. c. Kadri [2004] O.J. $\mathrm{n}^{\circ} 5018$. 
There are larger profits to be derived from immigration smuggling than from drugs. There is minimal risk, and the prison sentence is generally lower than for drug offenses. The proof is generally difficult. There is a neverending supply of people to serve. $(R . C . X u)$

L'ampleur du problème, ainsi que le nombre des pays et d'immigrants impliqués, est d'ailleurs considérée comme très inquiétante $(R . c . X u)$. Le phénomène du trafic de migrants est universel et en raison de sa gravité, il exige une réponse internationale, dont la signature du Protocole contre le trafic:

There is increasing international concern about the global problem of trafficking in people, where vulnerable people are exploited and exposed to dangerous circumstances. In fact, subsequent to this offence, Canada became a signatory to the United Nations Protocol Against Migrant Smuggling. (R. C. Li)

Depuis les attentats du 11 septembre 2001, l'immigration illégale est souvent associée au terrorisme. Cette préoccupation qui existe sur la place publique à l'égard de l'immigration irrégulière est également prise en considération par les tribunaux $(R . c . X u)$. L'arrivée de bateaux chargés de migrants causerait également la consternation dans l'opinion publique: «le prévenu s'est enrichi en profitant de la misère d'êtres humains qui recherchaient de meilleures conditions de vie» (R.c. Chowdbury).

En vertu des tribunaux, organiser l'entrée de personnes sans les documents de voyage valides au Canada est considéré de nature très sérieuse et, en conséquence, la peine reliée à cette offense devrait refléter cette gravité.

Contradiction entre le discours répressif et la sévérité de la peine

L'analyse normative démontre que la LIPR renforce les mesures normatives et prévoit des mesures d'exécution de la loi plus rigoureuses à l'égard des individus qui tentent de contourner la loi. Notre analyse jurisprudentielle vise à examiner comment cette sévérité législative est traduite par les tribunaux (voir annexe).

Les tribunaux pénaux visent la dissuasion du trafic

L'analyse jurisprudentielle permet d'identifier les objectifs pénologiques visés dans le cadre des infractions d'organisation de l'entrée irrégulière. 
Les finalités de la peine: dénonciation et dissuasion du trafic de migrants

Les tribunaux cherchent à envoyer un message explicite de désapprobation et de dénonciation à ceux qui tentent de migrer au Canada par des moyens illégaux (dissuasion générale) et à ceux qui profitent de cette situation et veulent s'enrichir dans le commerce de l'immigration illégale (dissuasion spéciale) (R. c. Mendez, R. c. Kadri et R. c. Damani).

The Crown argues that general deterrence is the issue and that sentencing in this case must send a message to the international community that Canada is not receptive to persons who would engage in this activity. (R. c. Tongo) It is necessary to send a clear message, not just to this individual but to others who might be tempted to involve themselves in this kind of misconduct. [...] And to a certain extent, any severity or harshness in sentencing today is going to send a message to others. (R. c. Graca)

Dans l'affaire R. c. Mubme, dans le but d'avoir un effet dissuasif, le procureur aux poursuites criminelles et pénales recommandait une période d'emprisonnement ainsi qu'une amende substantielle qui attaquerait directement la raison même de cette activité, c'est-à-dire le but lucratif. Notamment, du fait que dans ce cas, les migrants d'origine sikhe ont remboursé un montant total de plus que 122000 \$, le juge a finalement imposé une peine de 15 mois d'emprisonnement et $5000 \$$ d'amende.

Dans R. c. $L i$, sous l'ancienne loi, la juge Stromber-Stein poursuit également la dénonciation et la dissuasion du trafic de migrants. Pour y arriver, elle impose aux trafiquants une peine d'emprisonnement.

The growing trade in people smuggling must be deterred because it adversely impacts on all aspects of Canadian society. [...] This Court has an interest in stemming the flow of illegal migrants from Fujian Province by discouraging other like-minded individuals who consider participating in another highly profitable people smuggling enterprise. It is imperative that the message be conveyed that the Courts will not condone such activity. A sentence of four years is appropriate in all the circumstances.

Les facteurs de pondération dans les infractions de trafic de migrants

L'article 121 de la LIPR prévoit l'alourdissement de la peine si la victime a été soumise à un traitement humiliant ou dégradant en ce qui a trait 
aux conditions de travail, aux conditions sanitaires ou à l'exploitation sexuelle, ou si le geste a été fait en vue d'en tirer profit ou au bénéfice d'une organisation criminelle.

L'analyse judiciaire démontre que les tribunaux prennent en considération plusieurs circonstances, notamment la nature du crime, l'impact et les conséquences de l'immigration illégale, le rôle joué par l'accusé, la durée pendant laquelle les crimes ont été commis, les conditions et le traitement subis par les migrants et l'implication des organisations criminelles et leur niveau d'élaboration. La décision $R$. $c$. $L i$ est une référence importante quant aux décisions relatives au trafic de migrants (R. c. Chen, R. c. Tongo, R. c. Mendez, R. c. Damani). Sous l'ancien régime, la juge Stromberg-Stein condamna à quatre ans d'emprisonnement trois accusés qui avaient organisé, aidé ou encouragé l'entrée au Canada d'un groupe de 190 personnes qui n'étaient pas en possession des documents de voyage valides. Ce fut le troisième des quatre bateaux transportant des immigrants provenant de la Chine arrivés sur les côtes de Vancouver en 1999.

The appropriate sentence will reflect the nature and the gravity of the offence. The aggravating features loom large. This was obviously a lucrative criminal operation with financial gain as the motive. Each passenger owed $\$ 30$ to $\$ 40,000$ U.S. [...] It is an aggravating factor that the illegal migrants were brought to Canada in an unsafe, unseaworthy, unsanitary vessel, suffering deplorable conditions and being provided with inadequate food and water which was rationed. In addition to navigating treacherous waters in the dark, the bow of this unsafe vessel was badly damaged in a storm, probably a typhoon. There is evidence there were weapons on board the vessel - a gun and a knife - and evidence the gun was used to force compliance from at least one passenger. The illegal migrants were total strangers, with no connection to each other or to Canada.

Un autre cas, R. c. Damani, sous la LIPR, le juge André rapporte les circonstances aggravantes suivantes:

1. The scheme was well-planned and orchestrated;

2. It was a financial operation designed exclusively for pecuniary gain;

3. It was perpetrated over a significant time period and, involved the smuggling of a large number of illegal aliens;

4. It violated the immigration laws of a number of countries;

5. It jeopardized the chances of legitimate immigrants or genuine refugees seeking a safe haven in Canada or the United Stated;

6. It exposed both the United States and Canada to the risk of dangerous individuals' gaining surreptitious entry to these countries; 
7. It harmed the reputation of Canada by fostering an impression or belief that the country may afford a safe passage or conduit for illegal aliens intent on going to the U.S.;

8. The scheme imposed a severe burden on government resources, particularly those involving surveillance, processing of false refugee claims and prosecuting persons involved in such nefarious schemes;

9. Mr. Damani played a significant role in the conspiracy.

Le traitement des migrants et les conditions de voyage lors du trafic

L'insalubrité, l'insécurité du moyen de transport, le manque de nourriture et d'eau et le danger $(R . c . L i)$ sont des circonstances aggravantes. Les pays signataires du Protocole contre le trafic ont fait une mention particulière relative au trafic de migrants par mer (art. 7-9), en raison du risque accru que ce moyen de transport comporte pour les migrants. Cette vulnérabilité et le risque de victimisation accru des migrants sont également reflétés dans les décisions canadiennes:

It is an aggravating factor that the ship was unsafe, unseaworthy, unsanitary, and I agree that is the case here. When these accused decided to participate in this for some kind of a benefit and privileges to themselves, they were participating in a program in which a number of other people lived in deplorable conditions and which, as we know on the evidence, one person died be decision when she became ill there was simply no possible way to get any medical aid for her. (R. c. Chen)

La dimension de l'espace où le migrant a été confiné et les conditions de salubrité sont également des facteurs de pondération. Dans R. c. Mubme, l'avocat de la défense se réfère au cas du Bateau Amelie pour pondérer les circonstances aggravantes.

First of all, the «Amelie» transported 174 people. Secondly, the people on board the "Amelie» lived in abject poverty; they lived in the holds of an old cargo ship. It was unclean, it was never cleaned during passage. There was limited food available. There were no toilet facilities and the passengers were not permitted to see the light of day during the voyage.

\section{Le degré de responsabilisation de l'accusé}

Le degré d'implication de l'accusé dans l'organisation de l'entrée illégale est pris en compte dans le processus de détermination de la peine. 
L'étude jurisprudentielle permet de distinguer différents rôles: «substantial player [...] a person who is a cog in the wheel of trafficking in those buman beings and they're attempting to come in by illegal means into the country» (R. c. Mubme), "The success of the operation depended upon their participation [...] each accused played a pivotal role» (R. c. Li, R. c. Chen), "The accused was a "bit player", rather than a "key player". Defence argues that he is certainly not a "directing mind" of the conspiracy» (R. C. Xu), "But it really was a non-essential role» (R. c. Kadri).

I am satisfied that these two accused were far from being involved in any high level organization here. They were limited, in exchange for possibly a discount and some minimal privileges, to doing what they could to help everyone else on the ship make it across the Pacific without starving or getting into further difficulty. In that sense, they were pivotal, they were very important to the voyage and that activity of organizing in that sense and of aiding and abetting in this scheme is what is prescribed by the law and must be prescribed by the law. (R. c. Chen)

\section{Le degré d'élaboration de l'organisation criminelle}

L'élément d'élaboration et d'organisation du regroupement criminel est un facteur de pondération de la peine (R. c. Chen et $R$. c. Graca), respectant de cette manière les principes de détermination de la peine et les circonstances aggravantes prévues par le Code criminel (art. 718.2).

Relatively sophisticated planning and organization was required to undertake this people smuggling operation. The vessel had been equipped with relatively sophisticated communication and electronic equipment, some which could be used to avoid detection, most which was obviously thrown overboard before the boat was apprehended. (R. c. $L i)$

Les facteurs aggravants notés par la Cour sont la durée pendant laquelle les crimes ont été commis, qu'il ne s'agit pas d'un crime ponctuel, mais bien d'un mode de vie, qu'il s'agissait d'une organisation bien rodée ayant des méthodes assez sophistiquées. (R. c. Mozid Chowdhury)

Des réfugiés objets du trafic de migrants

Le fait que les migrants objets du trafic sont des réfugiés peut jouer comme circonstance atténuante (R. c. Kadri et $R$. c. Damani). Plusieurs juges canadiens tiennent compte du fait que le geste de l'accusé a pu sauver des personnes qui couraient un risque très élevé dans leur pays d'origine. 
Quant aux facteurs atténuants, la Cour a tenu compte de l'argument que les agissements du prévenu ont peut-être permis à certaines personnes de venir au Canada alors qu'elles étaient en danger dans leur pays. (R. c. Mozid Chowdhury)

Cela reflète une bonne compréhension et une grande sensibilisation des juges au phénomène de l'immigration forcée et au manque d'alternative pour des réfugiés que d'emprunter la voie irrégulière afin d'obtenir la protection du Canada (Jimenez, 2009b).

\section{Les peines infligées par les tribunaux pénaux contredisent l'objectif de dissuasion}

L'analyse jurisprudentielle de 19 décisions dans le cas de trafic de migrants illustre que les peines imposées par les tribunaux à partir de l'entrée en vigueur de la nouvelle législation semblent moins sévères que sous l'ancienne Loi sur l'immigration. Pourtant, la LIPR alourdit les peines à l'égard des infractions de l'entrée illégale au Canada. Sous l'ancien régime, les juges imposaient des peines privatives de liberté, souvent de trois et quatre ans (R. c. Chowdhury, R. c. Li, R. c. Min, R. c. $C h e n)$ et uniquement dans un cas, le juge avait ordonné une peine d'emprisonnement avec sursis (R. c. Balchand). Sous la LIPR, les tribunaux imposent des peines d'emprisonnement de plus courte durée, souvent de moins d'un an (R. c. Graca, R. c. Bello, R. c. Tongo) et généralement des peines d'emprisonnement avec sursis à purger dans la collectivité (R. c. Kadri, R. c. Damani, R. c. Samaroo). Or, la majorité des accusés sont membres d'organisations criminelles impliquées dans le trafic de migrants ayant réussi le passage illégal, à plusieurs reprises, d'un groupe de plus de dix migrants.

Bien que les discours politiques, parlementaires et judiciaires dénoncent la nature et la gravité de l'activité du trafic de migrants, dans la pratique, les sentences infligées sous la LIPR ne reflètent pas la sévérité attendue. Il existe donc une absence de corrélation et de proportionnalité entre la perception de la gravité du phénomène et la peine infligée au coupable de l'infraction de trafic de migrants. L'étude de deux cas démontre ce paradoxe. 


\section{Étude des cas R. c. Kadri ${ }^{9}$ et R. C. Damani ${ }^{10}$}

Dans les deux décisions rendues dans la même affaire, il est question d'un réseau de passeurs de migrants clandestins appartenant à une organisation criminelle, qui comptait au minimum 19 membres et qui opéra pendant une longue période de temps. Dans les décisions, le caractère transnational de l'organisation est établi, car elle s'occupait de faire pénétrer au Canada des migrants d'Asie méridionale, de l'Inde et du Pakistan, pour ensuite les transporter illégalement aux États-Unis. $\mathrm{Au}$ total, environ 300 migrants furent transportés. Le but lucratif de l'organisation a également été prouvé, chaque migrant payait jusqu'à 40000 \$ US pour être transporté en Amérique du Nord, ce qui rapportait plusieurs millions de dollars à l'organisation. Tous ces éléments confirment l'implication d'une organisation criminelle transnationale au sens du Protocole contre le trafic illicite et en vertu des définitions prévues par la législation canadienne, particulièrement dans le Code criminel et la LIPR. C'est la première fois que la loi sur l'appartenance à une organisation criminelle en vertu du Code criminel s'applique à un réseau de passeurs de migrants clandestins et donne lieu à des arrestations. Dans cette affaire, la Gendarmerie royale du Canada (GRC, 2001) avait investi beaucoup de ressources et travaillé en collaboration avec d'autres corps policiers, dont américains, pour mettre fin à ce réseau de passeurs de migrants. C'était une véritable opération policière à l'ampleur de la gravité et de la menace que semble représenter le phénomène du trafic de migrants.

\section{Le cadre juridique}

Les faits allégués et les éléments de preuve invoqués sont des infractions punies par différentes dispositions canadiennes. Tout d'abord, par la LIPR, article 117: «Organisation de l'entrée clandestine», passible d'une peine de détention pouvant aller jusqu'à l'emprisonnement à perpétuité et à une amende maximale d'un million de dollars. Avec l'application des circonstances aggravantes en vertu de l'article 121 (2): «si le geste a été posé en vue d'en tirer profit ou bénéfice d'une organisation criminelle», comme c'est le cas qui nous concerne. Deuxièmement, par le Code criminel, articles 467.1 (1) «organisation criminelle», 467.11 (1)

9. R. c. Kadri [2004] O.J. No. 5018.

10. R. c. Damani [2003] O.J. No. 5493. 
"participation aux activités d'une organisation criminelle», 465 (1)(c) «complot», 465 (3) «complot en vue de commettre une infraction à l'étranger» avec des circonstances aggravantes prévues par l'article 718.2 (iv) «l'infraction commise au profit ou sous la direction d'une organisation criminelle ou en association avec elle est considérée comme une circonstance aggravante».

\section{Les verdicts}

Dans R. c. Kadri, l'accusé a fait face à différents chefs d'accusation, dont celui de complot en vertu des lois américaines sur l'immigration, et de contribution illicite aux activités d'une organisation criminelle, contraire à l'article 465 (1)(c) du Code criminel. Lors de l'imposition de la peine, le juge Hawke de la Cour de justice ontarienne a soulevé plusieurs éléments importants allant à l'encontre d'une peine d'emprisonnement avec sursis. D'abord, la gravité et les impacts négatifs de l'infraction et l'objectif de dissuasion poursuivi:

I will first deal with the elements militating against a conditional sentence. The first one is the gravity of the offence. This is clearly a serious crime. Parliament has re-emphasized this point with new legislation and accompanying increased maximum penalties. The legislation referred to in Court is directed at immigration and security. In addition, as with basically all areas of criminal law, the fact that this is a conspiracy, in other words, a group of people organized to commit this offence, is of great concern. Returning to the immigration and security issues, activities such as this has a negative impact on legitimate claimants and on relationships with other countries, including our important neighbour to the South.

The second element militating against a conditional sentence is general deterrence. It really is an overriding principle in matters of this nature. Qualitatively, actual jail is perceived as more severe punishment. The principle of general deterrence is reinforced by the penalties in the new Act. It is clear that Parliament and the Courts are endeavoring to send a message, both nationally and internationally, that these matters are to be taken seriously and will be met with serious consequences.

Or, le juge conclut que Kadri n'avait pas un rôle de leader dans l'organisation criminelle, et dans une approche de justice réparatrice et dans un but de réhabilitation et de responsabilisation de l'individu, le juge Hawke a favorisé une peine d'emprisonnement avec sursis. Kadri a été condamné à purger une peine de 160 heures de services communautaires et un respect d'un couvre-feu. Le juge a considéré en temps double 
la période de 66 jours que Kadri a passée en détention équivalant à quatre mois et demi.

Damani a également fait face à un chef d'accusation de complot en vertu des lois américaines sur l'immigration, de contribution illicite aux activités d'une organisation criminelle, et de possession des produits de la criminalité (art. 465 [1][c| et [3] du Code criminel). Damani a plaidé coupable d'un chef d'accusation sous la LIPR en contravention de l'article 117. Le juge confirme la gravité de l'infraction et il veut envoyer un message clair à ceux qui seraient tentés de contourner les lois américaines et canadiennes d'immigration. Plusieurs circonstances aggravantes, entre autres le caractère lucratif, transnational et sophistiqué de l'infraction et le nombre important de migrants clandestins impliqués (300) dans la transaction ont été soulevés par le juge. Finalement, le juge a donné un équivalent de trois ans pour les 14 mois passés en détention préventive et il a condamné l'accusé à 12 mois supplémentaires à purger dans la collectivité.

Dans les cas de Kadri et Damani, les motifs du jugement sont très sérieux, la preuve documentaire est très solide et toutes les parties se rejoignent pour envoyer à travers la peine un message de dénonciation et de dissuasion. Cependant, les prévenus ont eu une peine d'emprisonnement avec sursis à purger dans la collectivité en vertu de l'article $742.1 \mathrm{du}$ Code criminel lorsque le tribunal est convaincu que le fait de purger la peine au sein de la collectivité ne met pas en danger la sécurité de celle-ci.

Nous considérons paradoxal que malgré le resserrement normatif et les objectifs pénologiques recherchés dans le cadre du trafic de migrants, une personne déclarée coupable d'être membre d'une organisation criminelle transnationale et impliquée dans le passage clandestin d'environ 300 migrants originaires de l'Inde et du Pakistan au Canada et aux États-Unis reçoive une peine à purger dans la collectivité. Cela signifie que le juge est convaincu que le condamné ne représente pas un danger pour la société. Les peines imposées dans les deux cas ne semblent pas proportionnelles à la gravité et à la nature dangereuse de l'infraction comme il est suggéré par les discours alarmistes et répressifs décrits par les organismes gouvernementaux et les décisions jurisprudentielles. 


\section{Conclusion}

La conception du trafic de migrants comme un crime est, comme pour n'importe quel délit, une construction sociale, politique et juridique des États. En effet, le fait de définir l'entrée dans un État dépourvue des documents requis comme une immigration illégale, ainsi que l'aide à l'organisation de cette entrée comme un trafic illicite de migrants, est une décision prise par l'État. Cette même construction sociale est également transférée lorsque le trafic de migrants est défini par l'État comme une menace ou un danger pour une société. De plus, par rapport à la peine attribuée à l'infraction, le gouvernement établit une catégorisation des crimes plus ou moins sévères. Lorsqu'un crime, tel que le trafic de migrants, est passible d'une peine susceptible d'atteindre l'emprisonnement à vie, l'État le qualifie a priori et délibérément de délit très grave qui mérite sa réprobation. En conséquence, l'État, en tant que responsable de la protection de la société contre le danger et la menace, établit un renforcement des mesures de sécurité en matière d'immigration pour lutter contre l'immigration irrégulière, le trafic de migrants et la traite des personnes. Notre analyse normative démontre un tel renforcement par le gouvernement canadien.

Paradoxalement, l'analyse jurisprudentielle démontre un écart important entre les discours politiques et législatifs visant la lutte contre la criminalité organisée et l'immigration illégale et l'application des mesures pénales pour les combattre. D'un côté, il existe un discours politique qui dénonce la menace et les conséquences négatives du trafic de migrants et de la criminalité transnationale organisée au Canada. Le législateur canadien prévoit un renforcement des peines pour s'attaquer aux phénomènes. D'un autre côté, nous constatons que les peines infligées aux coupables du trafic de migrants ne reflètent pas cette gravité de l'infraction. Nous nous interrogeons sur la fonctionnalité du renforcement des peines et de l'augmentation des peines maximales si, dans la pratique, les sentences ne traduisent pas cette sévérité.

Afin d'envoyer un message politique à la population, l'incrimination et l'aggravation des peines maximales du trafic de migrants auraient une fonction nettement symbolique, donnant l'impression que le gouvernement canadien est en action et qu'il s'attaque au problème. Or, l'augmentation de l'incrimination légale peut donner un faux sentiment de sécurité, car il n'atteindrait pas l'effet d'exemplarité du fait que les 
peines imposées par les tribunaux canadiens ne sont pas en corrélation avec le renforcement normatif.

Finalement, comme expliqué par le modèle du cercle vicieux du resserrement des frontières, tant qu'il y aura des individus qui sentent leur vie en danger ou leurs droits civiques bafoués dans leur pays d'origine et qui sont prêts à tout risquer pour tenter une vie en sécurité ailleurs, il y aura toujours des personnes prêtes à combler cette demande. Or, les moyens pour combattre le trafic de migrants doivent être ciblés à différents niveaux et non uniquement de façon répressive.

\section{Références}

Bigo, D. (2005). La mondialisation de 1'(in)sécurité. Cultures et Conflits, 58 (été 2005), 53-101.

Bigo, D. (2006). Security, exception, ban and surveillance. In D. Lyon (ed.), Theorizing Surveillance, the Panopticon and Beyond (46-68). Kingston: Willan.

Bigo, D. (2007). Detention of foreigner, states of exception, and the social practices of control of the Banopticon. In P. Kumar Rajaram \& C. Grundy Warr (eds.), Borderscapes: Hidden geographies and politics at territory's edge (3-34). Minneapolis: University of Minesotta Press.

Canada. (2002). Le Canada ratifie la Convention des Nations Unies sur la criminalité transnationale organisée (Communiqué de presse, 14 mai). Ottawa: Ministère des Affaires étrangères et du Commerce international. Consulté le 16 mai 2002, http://webapps.dfait-maeci.gc.ca/minpub/Publication.asp?publication $\_$id $=379257$ \& Language $=\mathrm{F}$

Canada. (2012). De meilleurs outils pour poursuivre en justice les passeurs de clandestins et leur imposer des peines d'emprisonnement obligatoires (Document d'information). Ottawa: Ministère de la Citoyenneté et Immigration. Consulté le 26 mars 2012, http://www.cic.gc.ca/francais/ministere/media/documentsinfo/2012/2012-02-16j.asp

Chin, K.-L. (2000). Smuggled Chinese: Clandestine migration to the United States. Philadelphia: Temple University Press.

Chin, K.-L. (2001). The social organisation of Chinese human smuggling. In D. Kyle \& R. Koslowski (eds.), Global Human Smuggling Perspectives (216234). London \& Baltimore: The Johns Hopkins university press.

Crépeau, F., \& Jimenez, E. (2002). L'impact de la lutte contre le terrorisme sur les libertés fondamentales au Canada. In E. Bribosia \& A. Weyembergh (eds.), Lutte contre le terrorisme et droits fondamentaux, collection «Droit et Justice " (249-287). Bruxelles: Bruylant.

Crépeau, F., \& Nakache, D. (2006). Controlling irregular migration in Canada: Reconciling security concerns with human rights protection. IRPP Choices, $12(1)$. 
Crépeau, F., Nakache, N., \& Atak, I. (2007). International migration: Security concerns and human rights standards. Transcultural Psychiatry, 44 (3), 311337.

Crépeau, F., Nakache, D., \& Atak, I. (2009). Les migrations internationales contemporaines - Une dynamique complexe au cour de la globalisation. Montréal: Presses de l'Université de Montréal.

De Pierrebourg, F. (2011). Baisse des voyageurs illégaux dans les aéroports canadiens, La presse (2 décembre). Consulté le 4 février 2013, http://www. cyberpresse.ca/actualites/quebec-canada/national/201112/02/014473774-baisse-des-voyageurs-illegaux-dans-les-aeroports-canadiens.php

Finckenauer, J. O., \& Waring, E. J. (1998). Russian mafia in America. Boston: Northeastern University Press.

Gendarmerie royale du Canada. (2001). Réseau de passeurs démantelé par la Gendarmerie royale du Canada (Communiqué de presse, 7 octobre 2001). Consulté le 13 novembre 2001, http://www.rcmp-grc.ca/on/press/2002/2002_ oct_07_f.htm.

Jimenez, E. (2009a). La distinction problématique entre la traite des personnes et le trafic de migrants risque de laisser sans protection les victimes de la traite. In M. Claude, N. Laviolette \& R. Poulin (eds.), Prostitution et traite des êtres bumains, enjeux nationaux et internationaux (113-141). Ottawa: Éditions L'Interligne.

Jimenez, E. (2009b). L'immigration irrégulière et le trafic des migrants comme ultime recours pour atteindre le Canada: L'expérience migratoire des demandeurs d'asile. Refuge, 26 (1), 148-160.

Jimenez, E. (2010a). Le combat contre le trafic des migrants au Canada: Contrôle migratoire d'abord, lutte au crime organisé ensuite. Berlin: Éditions Universitaires Européennes.

Jimenez, E. (2010b). L'immigrant est-il perçu comme une menace à la sécurité nationale? In D. Lafortune, J. Poupart \& S. Tanner (dir.), Collectif pour le $50^{e}$ anniversaire de l'École de criminologie de l'Université de Montréal: Questions de criminologie. Montréal: Presses de l'Université de Montréal.

Kozlowski, R. (2001). Economic globalization, human smuggling, and global governance. In D. Kyle \& R. Kozlowski (eds.), Global buman smuggling: Comparative perspectives (337-358). Baltimore: Johns Hopkins University Press.

Kyle, D., \& Liang, Z. (2001). Migrant merchants: Organized migrant trafficking from China and Ecuador (Working paper $\mathrm{n}^{\circ} 43$ ). San Diego: The Center for Comparative Immigration Studies (CCIS), University of California.

Lowry, M. (2002). Creating human insecurity: The national security focus in Canada's immigration system. Refuge, 21 (1), 28-37.

Macklin, A. (2001). Borderline security. In R. Daniels, P. Macklem \& K. Roach (eds.), The Security of Freedom: Essays on Canada's Anti-Terrorism Bill (383-405). Toronto: University of Toronto Press.

Meunier, H. (2012). Sur la trace des sans-papiers. La Presse (8 février). Consulté le 8 février 2012, http://www.cyberpresse.ca/actualites/quebec-canada/ 
national /201202/07/01-4493678-sur-la-trace-des-sans-papiers.php?utm categorieinterne $=$ trafficdrivers $\&$ utm_contenuintern $e=$ cyberpresse_vous_ suggere_4494084_article_POS1

Schloenhardt, A. (2003). Migrants smuggling: Illegal migration and organized crime in Australia and the Asia Pacific region. Leiden-Boston: Martinus Nijhoff Publishers.

Skeldon, R. (2000). Trafficking: A perspective from Asia. In R. Appleyard \& J. Salt (dir.), Perspectives on Trafficking of Migrants (7-30). Genève, ONU et OIM.

Tsoukala, A. (1997). Contrôle de l'immigration: mythes et réalités. Cultures $\mathfrak{F}$ Conflits, 26/27, 9-14. Consulté le 4 février 2013, http://www.conflits.org/ document 356.html.

Vlassis, D. (2001). The United Nations Convention against transnational organized crime and its protocols: A new era in international cooperation. In The Changing Face of International Criminal Law (75-103). Vancouvert: The International Centre for International Criminal Law Reform and Criminal Justice policy

\section{Les lois et règlements canadiens}

Code criminel (L.R.C. (1985), ch. C-46)

Loi sur l'immigration et la protection des réfugiés. L.C. 2001, c. 27.

\section{Lois internationales}

Protocole contre le trafic illicite de migrants par terre, air et mer additionnel à la Convention des Nations Unies contre la criminalité transnationale organisée, adopté le 15 novembre 2000 et entré en vigueur le 28 janvier 2004. http://www.uncjin. org/Documents/Conventions/dcatoc/final_documents_2/convention_ smug_french.pdf.

ABSTRACT - Irregular migration is perceived by the international community as a security issue. The criminalization of immigration becomes a tool for migration control and border security. In recent years, Canada adopted a punitive approach and increasingly relied on the criminalization of irregular migration, introducing more severe penalties including life imprisonment. Paradoxically, despite tougher legislation, including the adoption of mandatory minimum sentences and increasing maximum sentences, Canadian courts tend to impose short-term prison sentences on smugglers and usually conditional sentences to be served in the community. This paper presents the results of a legal analysis relating to the smuggling of migrants in Canada. The results show that sentences granted by the courts are not proportional to the political discourse and alarmist messages in the media regarding the threat posed by the smuggling of migrants.

KEYWORDS - Smuggling in migrants, border securitization, criminalization, legal analysis. 
RESUMEN - La migración irregular es percibida por la comunidad internacional como una cuestión de seguridad. La criminalización de la inmigración se vuelve, entonces, una herramienta de control migratorio y de seguridad de las fronteras. En el transcurso de los últimos años, Canadá ha adoptado un enfoque punitivo y un mayor recurso a la criminalización de la inmigración irregular, con penas que pueden llegar, incluso, a la encarcelación de por vida. Paradójicamente, a pesar de un fortalecimiento normativo, que incluye la adopción de penas mínimas obligatorias, así como la aumentación de las penas máximas, los tribunales canadienses imponen a los inmigrantes ilegales, penas de encarcelación de corta duración y, generalmente, penas de encarcelación con posibilidad de purgar en la comunidad. El presente artículo presenta los resultados de análisis legislativos y jurisprudenciales relativos al trafico de migrantes en Canadá. Los resultados demuestran que las sanciones impuestas por los tribunales no son proporcionales a los discursos alarmistas políticos y mediáticos con respecto a la amenaza que representa la organización de la entrada ilegal.

PALABRAS CLAVE - Trafico de migrantes, seguridad de las fronteras, criminalización, análisis jurisprudencial. 


\section{ANNEXE}

TAB LEA U 1

\section{Les peines imposées lors des infractions relatives au trafic de migrants sous l'ancienne Loi sur l'immigration et l'actuelle Loi sur l'immigration et la protection des réfugiés ${ }^{11}$}

\begin{tabular}{|c|c|c|c|}
\hline \multicolumn{4}{|c|}{ Ancienne Loi sur l'immigration } \\
\hline Cas & Faits prouvés & $\begin{array}{l}\text { Articles fondant la } \\
\text { décision }\end{array}$ & Peine \\
\hline $\begin{array}{l}\text { Affaire Bateau } \\
\text { Amelie (non } \\
\text { raportée) (1987) } \\
\text { (cité dans } R . C . \\
\text { Muhme [1992]) }\end{array}$ & $\begin{array}{l}\text { Débarquement dans la } \\
\text { mer de } 174 \text { Sikhs sur } \\
\text { les côtes de la } \\
\text { Nouvelle-Écosse. } \\
\text { Mauvaises conditions } \\
\text { et traitement inhumain } \\
\text { des migrants. }\end{array}$ & $\begin{array}{l}\text { Art. } 94.1 \text { Loi sur } \\
\text { l'immigration } \\
\text { L. R. C. (1985). }\end{array}$ & $\begin{array}{l}\text { Au capitaine du } \\
\text { bateau: } 1 \text { an } \\
\text { d'emprisonnement } \\
+ \text { une amende de } \\
\text { 5,000 } \$ \\
\text { Aux membres de } \\
\text { l'équipage: } 1 \text { mois } \\
\text { d'emprisonnement. }\end{array}$ \\
\hline $\begin{array}{l}\text { R. c. King Fong } \\
\text { Yue } \\
{[1991]}\end{array}$ & $\begin{array}{l}\text { Membre d'une } \\
\text { organisation criminelle } \\
\text { chargée d'entrer } \\
\text { illégalement des } \\
\text { Chinois au Canada. }\end{array}$ & Art. 94.2. & $\begin{array}{l}22 \text { mois d'emprisonne- } \\
\text { ment }(+7 \text { mois en } \\
\text { détention préventive). }\end{array}$ \\
\hline $\begin{array}{l}\text { R. c. Muhme } \\
\text { [1992] }\end{array}$ & $\begin{array}{l}\text { Organisation d'entrée } \\
\text { illégale de } 13 \text { Indiens } \\
\text { sikhs par bateau au } \\
\text { port d'Halifax. } \\
\text { Chaque migrant payait } \\
9400 \$ \text {. }\end{array}$ & $\begin{array}{l}\text { Art. } 94.2 \text {, aider ou } \\
\text { organiser l'entrée au } \\
\text { Canada de } 10 \text { person- } \\
\text { nes et plus sans les } \\
\text { documents valides. }\end{array}$ & $\begin{array}{l}15 \text { mois d'emprisonne- } \\
\text { ment }+5000 \$ \\
\text { d'amende. }\end{array}$ \\
\hline $\begin{array}{l}\text { Mahmood c. } \\
\text { Canada } \\
{[2000]}\end{array}$ & $\begin{array}{l}\text { Utilisation de son } \\
\text { passeport pour obtenir } \\
\text { une carte d'embarque- } \\
\text { ment à destination de } \\
\text { Vancouver pour un ami. }\end{array}$ & $\begin{array}{l}\text { Art. } 10 \text { (b) du Décret } \\
\text { sur les passeports } \\
\text { canadiens: un } \\
\text { passeport peut être } \\
\text { révoqué si une } \\
\text { personne utilise le } \\
\text { passeport pour } \\
\text { commettre dans un } \\
\text { pays étranger toute } \\
\text { infraction qui } \\
\text { constituerait un acte } \\
\text { criminel (art. 94.1) si } \\
\text { elle était commise au } \\
\text { Canada. }\end{array}$ & $\begin{array}{l}\text { Révocation du } \\
\text { passeport canadien. }\end{array}$ \\
\hline $\begin{array}{l}\text { R. c. Mozid } \\
\text { Chowdhury } \\
{[2000]}\end{array}$ & $\begin{array}{l}\text { Organisation de } \\
\text { l'entrée illégale au } \\
\text { Canada de } 19 \\
\text { personnes provenant } \\
\text { du Bangladesh en } \\
\text { échange de } \\
18000 \$-45000 \$ \text {. }\end{array}$ & $\begin{array}{l}\text { Art. } 94.1(\mathrm{a}) . \\
\text { D'avoir agi comme } \\
\text { passeur. }\end{array}$ & $\begin{array}{l}3 \text { ans d'emprisonne- } \\
\text { ment pour chacun des } \\
\text { chefs avec confusion } \\
\text { des peines. }\end{array}$ \\
\hline
\end{tabular}

11. Le tableau a été complété avec les informations recueillies à la suite de l'analyse jurisprudentielle, plusieurs données (article fondant la décision, peine, facteurs de pondération...) sont manquantes. 


\begin{tabular}{|c|c|c|c|}
\hline $\begin{array}{l}\text { R. C. L. } \\
{[2001]}\end{array}$ & $\begin{array}{l}\text { Organisation de l'entrée } \\
\text { du } 3^{e} \text { des } 4 \text { bateaux } \\
\text { arrivés à Vancouver } \\
\text { amenant } 190 \\
\text { immigrants chinois sans } \\
\text { documents en échange } \\
\text { de } 30000-40000 \$ \text {. } \\
\text { Mauvaises conditions et } \\
\text { traitement inhumain } \\
\text { des migrants. }\end{array}$ & Art. 94.2. & $\begin{array}{l}4 \text { ans d'emprisonne- } \\
\text { ment. }\end{array}$ \\
\hline $\begin{array}{l}\text { R. c. Min } \\
{[2001]}\end{array}$ & $\begin{array}{l}\text { À la tête de l'organisa- } \\
\text { tion du passage illégal } \\
\text { aux États-Unis par le } \\
\text { Canada de } 400 \text { migrants } \\
\text { asiatiques entre } \\
\text { novembre } 2000 \text { et mars } \\
2001 .\end{array}$ & & $\begin{array}{l}4 \text { ans d'emprisonne- } \\
\text { ment. }\end{array}$ \\
\hline $\begin{array}{l}\text { R. c. Chen } \\
\text { [2001] }\end{array}$ & $\begin{array}{l}\text { Aider à l'organisation } \\
\text { du voyage de } 131 \\
\text { migrants chinois arrivés } \\
\text { par bateau. } \\
\text { Ils font partie des } \\
\text { passagers. } \\
\text { Mauvaises conditions et } \\
\text { traitement inhumain } \\
\text { des migrants. }\end{array}$ & Art. 94.2. & $\begin{array}{l}4 \text { ans d'emprisonne- } \\
\text { ment. }\end{array}$ \\
\hline $\begin{array}{l}\text { R. c. Xu } \\
{[2001]}\end{array}$ & $\begin{array}{l}\text { Organisation du } \\
\text { passage illégal aux } \\
\text { États-Unis par le } \\
\text { Canada de migrants } \\
\text { entre juillet } 2000 \text { et } \\
\text { février } 2001 .\end{array}$ & $\begin{array}{l}\text { Art. } 94.1+ \\
\text { Art } 465(1)(\text { c) du Code } \\
\text { criminel. } \\
\text { Avoir comploté avec } 17 \\
\text { ou } 18 \text { individus pour } \\
\text { passer illégalement des } \\
\text { migrants aux États-Unis } \\
\text { par le Canada. }\end{array}$ & \\
\hline $\begin{array}{l}\text { R. c. Li, Chen and } \\
\text { Li, } \\
\text { [2002] }\end{array}$ & $\begin{array}{l}\text { Participation dans une } \\
\text { organisation criminelle } \\
\text { qui trafique les } \\
\text { migrants chinois au } \\
\text { Canada pour réduire } \\
\text { leur dette contractée } \\
\text { par leur propre trafic. } \\
\text { Enlèvement de } 3 \\
\text { membres d'une famille } \\
\text { pendant } 22 \text { jours. }\end{array}$ & & $\begin{array}{l}\text { Réduction de la peine à } \\
\text { vie à } 14 \text { ans d'empri- } \\
\text { sonnement + ordre de } \\
\text { déportation. }\end{array}$ \\
\hline $\begin{array}{l}\text { R. c. Balchand } \\
\text { [2002] }\end{array}$ & $\begin{array}{l}\text { Passage illégal de } \\
\text { personnes aux } \\
\text { États-Unis par le } \\
\text { Canada. }\end{array}$ & & $\begin{array}{l}6 \text { mois d'emprisonne- } \\
\text { ment avec sursis. }\end{array}$ \\
\hline $\begin{array}{l}\text { R. c. Mendez } \\
\text { [] }\end{array}$ & $\begin{array}{l}\text { Étant consultante en } \\
\text { immigration, a conseillé } \\
\text { à plusieurs clients de } \\
\text { faire des fausses } \\
\text { déclarations lors de la } \\
\text { demande de statut de } \\
\text { réfugié. }\end{array}$ & Art. 94.5. & $\begin{array}{l}9 \text { mois d'emprisonne- } \\
\text { ment. }\end{array}$ \\
\hline $\begin{array}{l}\text { R. c. Roo } \\
\text { [] }\end{array}$ & $\begin{array}{l}\text { A trafiqué } 31 \text { migrants } \\
\text { dans } 5 \text { voyages } \\
\text { différents à travers la } \\
\text { frontière Canada-États- } \\
\text { Unis. }\end{array}$ & & $\begin{array}{l}34 \text { mois d'emprisonne- } \\
\text { ment. }\end{array}$ \\
\hline
\end{tabular}




\begin{tabular}{|c|c|c|c|}
\hline \multicolumn{4}{|c|}{ Actuelle Loi sur l'immigration et la protection des réfugiés } \\
\hline $\begin{array}{l}\text { R. c. Tongo } \\
{[2002]}\end{array}$ & $\begin{array}{l}\text { Aider à entrer } \\
\text { illégalement au Canada } \\
3 \text { migrants chinois } \\
\text { cachés dans leur } \\
\text { compartiment du } \\
\text { bateau. }\end{array}$ & $\begin{array}{l}\text { LIPR 117(1), 117(4), } \\
118,119,127(\mathrm{a})\end{array}$ & $\begin{array}{l}5 \text { mois d'emprisonne- } \\
\text { ment. }\end{array}$ \\
\hline $\begin{array}{l}\text { R. c. Graprasad } \\
\text { (a) et Samaroo } \\
\text { (b) } \\
{[2003]}\end{array}$ & $\begin{array}{l}\text { Participation au } \\
\text { passage illégal de } 40 \\
\text { personnes aux } \\
\text { États-Unis par le } \\
\text { Canada, } 20 \text { voyages } \\
\text { pendant } 8 \text { mois. }\end{array}$ & $\begin{array}{l}\text { La loi américaine en } \\
\text { immigration. }\end{array}$ & $\begin{array}{l}\text { a) Récidiviste: } \\
3 \text { ans d'emprisonne- } \\
\text { ment; } \\
\text { b) } 1^{\text {re }} \text { offense: } 2 \text { ans } \\
\text { moins } 1 \text { jour, } \\
\text { emprisonnement avec } \\
\text { sursis. }\end{array}$ \\
\hline $\begin{array}{l}\text { R. c. Damani } \\
{[2003]}\end{array}$ & $\begin{array}{l}\text { Membre d'un réseau de } \\
\text { passeurs de migrants } \\
\text { provenant de l'Inde et } \\
\text { du Pakistan aux } \\
\text { États-Unis par le } \\
\text { Canada; environ } 300 \\
\text { migrants furent } \\
\text { transportés. } \\
\text { Implication dans } \\
8 \text { passages transpor- } \\
\text { tant } 61 \text { migrants, dont } \\
28 \text { ayant réussi. } \\
\text { Coût du passage de } \\
\text { frontière de } \\
2500 \$-3000 \$ \text { US. }\end{array}$ & $\begin{array}{l}\text { Charges of conspiracy } \\
\text { to violate the United } \\
\text { States Immigration } \\
\text { laws by causing } \\
\text { persons to come to the } \\
\text { United States } \\
\text { unlawfully. Loi sur } \\
\text { l'immigration: } \\
\text { Art. } 94.1,94.1(\mathrm{~m}) \text {, } \\
94.1(\mathrm{~m})(\mathrm{a}) \text {. } \\
\text { Code criminel: } 465(3) \\
\text { et } 465(1)(\mathrm{c}) \text { et d'être } \\
\text { en possession de biens } \\
\text { criminels contraire à } \\
\text { l'art. } 354(1)(\mathrm{b}) \text {. } \\
\text { LIPR: un chef } \\
\text { d'accusation prévu } \\
\text { dans le chapitre } 27 \text { et } \\
\text { l'art. } 117(1) \text {. }\end{array}$ & 4 ans. \\
\hline $\begin{array}{l}\text { R. c. Kadri } \\
{[2004]}\end{array}$ & $\begin{array}{l}\text { Membre d'un réseau de } \\
\text { passeurs de migrants } \\
\text { provenant de l'Inde et } \\
\text { du Pakistan aux } \\
\text { États-Unis par le } \\
\text { Canada. Environ } 300 \\
\text { migrants furent } \\
\text { transportés (même } \\
\text { réseau que Damani). } \\
\text { Complot en vertu des } \\
\text { lois américaines sur } \\
\text { l'immigration. } \\
\text { Contribution illicite } \\
\text { aux activités d'une } \\
\text { organisation } \\
\text { criminelle. } \\
\text { Responsable } \\
\text { d'effectuer } 14 \text { passages } \\
\text { et de traverser } \\
65 \text { migrants à travers } \\
\text { la frontière canado- } \\
\text { américaine. }\end{array}$ & $\begin{array}{l}\text { Complot en vertu des } \\
\text { lois américaines sur } \\
\text { l'immigration. } \\
\text { Contribution illicite } \\
\text { aux activités d'une } \\
\text { organisation criminelle } \\
\text { S. } 465(1)(c) \text { Code } \\
\text { criminel. }\end{array}$ & $\begin{array}{l}160 \text { heures de services } \\
\text { communautaires } \\
\text { ( }+66 \text { jours de } \\
\text { détention préventive } \\
\times 2=41 / 2 \text { mois). }\end{array}$ \\
\hline $\begin{array}{l}\text { R. c. Graca } \\
{[2003]}\end{array}$ & $\begin{array}{l}\text { Aider une famille au } \\
\text { passage illégal de la } \\
\text { frontière Canada-États- } \\
\text { Unis. }\end{array}$ & Art. 127 (a) de la LIPR. & $\begin{array}{l}65 \text { jours d'emprisonne- } \\
\text { ment. }\end{array}$ \\
\hline $\begin{array}{l}\text { R. c. Bello } \\
{[2004]}\end{array}$ & $\begin{array}{l}\text { Aider ou organiser } \\
\text { l'entrée au Canada sans } \\
\text { documents valides. }\end{array}$ & $\begin{array}{l}\text { Arts. } 117 \text { (1) et } 131 \text { de } \\
\text { la LIPR. }\end{array}$ & $\begin{array}{l}1 \text { jour }(+51 / 2 \text { mois en } \\
\text { détention préventive } \\
\times 2)\end{array}$ \\
\hline
\end{tabular}

